\title{
Surface plasmon resonance aptasensor based on niobium carbide MXene quantum dots for nucleocapsid of SARS-CoV-2 detection
}

\author{
Rongyuan Chen ${ }^{1} \cdot$ Lun Kan $^{1} \cdot$ Fenghe Duan ${ }^{1} \cdot$ Linghao He $^{1} \cdot$ Minghua Wang ${ }^{1} \cdot$ Jing Cui $^{1} \cdot$ Zhihong Zhang $^{1}$. \\ Zhonghou Zhang ${ }^{1}$
}

Received: 21 April 2021 / Accepted: 11 August 2021 / Published online: 2 September 2021

(C) The Author(s), under exclusive licence to Springer-Verlag GmbH Austria, part of Springer Nature 2021

\begin{abstract}
A novel label-free surface plasmon resonance (SPR) aptasensor has been constructed for the detection of N-gene of SARS-CoV2 by using thiol-modified niobium carbide MXene quantum dots $\left(\mathrm{Nb}_{2} \mathrm{C}-\mathrm{SH}\right.$ QDs) as the bioplatform for anchoring $\mathrm{N}$-genetargeted aptamer. In the presence of SARS-CoV-2 N-gene, the immobilized aptamer strands changed their conformation to specifically bind with N-gene. It thus increased the contact area or enlarged the distance between aptamer and the SPR chip, resulting in a change of the SPR signal irradiated by the laser (He-Ne) with the wavelength $(\lambda)$ of $633 \mathrm{~nm} . \mathrm{Nb}_{2} \mathrm{C}$ QDs were derived from $\mathrm{Nb}_{2} \mathrm{C}$ MXene nanosheets via a solvothermal method, followed by functionalization with octadecanethiol through a self-assembling method. Subsequently, the gold chip for SPR measurements was modified with $\mathrm{Nb}_{2} \mathrm{C}-\mathrm{SH}$ QDs via covalent binding of the Au-S bond also by self-assembling interaction. $\mathrm{Nb}_{2} \mathrm{C}$-SH QDs not only resulted in high bioaffinity toward aptamer but also enhanced the SPR response. Thus, the $\mathrm{Nb}_{2} \mathrm{C}-\mathrm{SH}$ QD-based SPR aptasensor had low limit of detection (LOD) of $4.9 \mathrm{pg} \mathrm{mL}^{-1}$ toward $\mathrm{N}$-gene within the concentration range 0.05 to $100 \mathrm{ng} \mathrm{mL}^{-1}$. The sensor also showed excellent selectivity in the presence of various respiratory viruses and proteins in human serum and high stability. Moreover, the $\mathrm{Nb}_{2} \mathrm{C}-\mathrm{SH}$ QD-based SPR aptasensor displayed a vast practical application for the qualitative analysis of $\mathrm{N}$-gene from different samples, including seawater, seafood, and human serum. Thus, this work can provide a deep insight into the construction of the aptasensor for detecting SARS-CoV-2 in complex environments.
\end{abstract}

Keywords $\mathrm{Nb}_{2} \mathrm{C}$ MXene quantum dot $\cdot$ Surface plasmon resonance biosensor $\cdot$ Aptasensor $\cdot$ Detection of N-gene $\cdot \mathrm{SARS}-\mathrm{CoV}-2$

\section{Introduction}

Since the end of 2019, the world has been suffering from the COVID-19 pandemic caused by novel SARS-CoV-2 coronavirus. This disease has spread across 205 countries and territories, infected more than one hundred million individuals, and resulted in 2 million mortalities [1]. The early clinical manifestations of COVID-19 are similar to the symptoms of the severe acute respiratory syndrome and Middle East respiratory syndrome coronavirus disease, namely, fever,

Zhihong Zhang

mainzhh@163.com

Zhonghou Zhang gxnc1272@163.com

1 College of Material and Chemical Engineering, Zhengzhou University of Light Industry, No. 136, Science Avenue, Zhengzhou 450001, People's Republic of China headache, myalgia, arthralgia, and lymph node enlargement. SARS-CoV-2 is characterized with moderate mortality rate, high infection rate, and longer incubation period, leading to long-term infection [2]. Thus, COVID-19 threatens the safety of people and causes serious financial crises. SARS-CoV-2 has been identified in diverse environments, such as water systems, frozen foods, or food packaging [3, 4]. Thereby, the rapid diagnosis of the COVID-19 virus is highly essential to control efficiently the spread of the virus and treat patients. Similar to other coronaviruses, SARS-CoV-2 is composed mainly of four structural proteins, namely, the spike (S), membrane $(\mathrm{M})$, envelop $(\mathrm{E})$, and nucleocapsid $(\mathrm{N})$ proteins [5]. The proteins (e.g., S protein) [6] and viral RNA [7] can be used as targets for the qualitative and quantitative analyses of COVID-19. Alternatively, antibodies, such as IgM and IgG, from patient samples can also be detected to probe the infection history [8]. Diverse techniques have been developed to analyze SARS-CoV2, such as real-time polymerase chain reaction (PCR) [9], colorimetric assay [10], surface plasmon 
resonance (SPR) and localized SPR [11], electrochemical approaches [9, 12-15], optics methods [16, 17], optical/ chemiluminescence immunosensors [18], fluorescent technique [19], wearable sensor [20], and isothermal rolling circle amplification (RCA) [21]. Although many studies have focused on the sensitive determination methods of SARSCoV-2 [22-25], COVID-19 has resulted in a heavy burden for health systems and human society. Consequently, advanced and sensitive determination methods should be developed to assess SARS-CoV-2 in different environments and populations.

Most techniques have been formulated based on the specific recognition between antibodies and diverse proteins and RNAs in the SARS-CoV-2 virus. Compared with antibodies, as a powerful class of probes, DNA aptamers have some advantages, such as high specificity, strong affinity, rapid and reliable synthesis, ease of conjugation, and high feasibility to bind with other DNA-based reactions for efficient signal amplification. Thus, aptamers can be used in different applications for in vitro and in vivo diagnoses. Diverse techniques, such as PCR [26], electrochemical methods [27], and fluorescence approach [28], have been combined with aptasensors for analyzing biomarkers of SARS-CoV-2. However, the aforementioned techniques have some disadvantages. For example, PCR is more complex with need to achieve appropriate test conditions, often leading to low accuracy [29]; detection kits often exhibit low sensitivity for the analysis of SARSCoV2 [30]. As for SPR sensing strategy, it is often applied for the construction of diverse immunoassays, for multiple detection of biomolecules, and in situ determination interactions of multiplexed chemical and biological analytes, such as interactions between antibodies and antigens, RNAs, DNAs, or proteins, and a wide variety of ligands or targets [31]. Although different SPR immunosensors have been constructed for detecting antibodies against SARS-CoV-2 [32-34], no SPR aptasensor for analyzing the RNA of $\mathrm{N}$-gene has been reported yet.

Various nanomaterials, such as functional polymers [35], nanoparticles [36], graphene [37, 38], MXene nanosheets [39, 40], and $\mathrm{MoS}_{2}$ [41], have been utilized as sensing platforms for the fabrication of SPR aptasensors. MXenes, which are known as two-dimensional materials, have attracted extensive attention due to their similar structure and analogous performances to graphene. The versatile chemical structure, compositions, and tunable surface functionalization of MXenes facilitate the diverse applications of MXene, such as in solar cells [42], electronic devices [43], catalysts [44, 45], gas sensors or biosensors [46, 47], and cancer therapy [48]. MXenes have nanosheet-like structure, unique surface chemistry, high conductive properties, and excellent biocompatibility. These characteristics allow MXenes to efficiently act as platforms for the development of diverse biosensors [49, 50]. MXene nanosheets have been explored as a sensitive layer for immobilizing probes and developing SPR biosensors [40, 51]. However, the ultrathin MXene nanosheets are prone to aggregate to bulk size due to the $\pi-\pi^{*}$ stacking interaction. Optimal MXene nanosheets for the development of the SPR biosensor are difficult to obtain because of the limitation in the thickness of SPR biosensors, in which the sensitive layer is $\sim 200 \mathrm{~nm}$ [52]. By contrast, zero-dimensional $\mathrm{Ti}_{3} \mathrm{C}_{2}$ quantum dots (QDs) from 2D bulk MXene demonstrate novel properties relative to their $2 \mathrm{D}$ counterparts because of a combination of quantum confinement, edge effect, and surface functionality [53]. Thus, MXene QDs can be utilized as sensitive nanomaterials to construct SPR aptasensors for detecting Ngene of SARS-CoV-2.

In this work, we have designed and constructed a novel SPR biosensor by using niobium carbide MXene QDs functionalized with the thiol group (denoted as $\mathrm{Nb}_{2} \mathrm{C}-\mathrm{SH}$ QDs) as the bioplatform for adsorbing N-gene-targeted N58 aptamer. The biosensor was explored for the sensitive detection of $\mathrm{N}$ gene from diverse complex environments, such as human serum, seawater, and seafood (Fig. 1). $\mathrm{Nb}_{2} \mathrm{C}$ QDs were derived from $\mathrm{Nb}_{2} \mathrm{C}$ MXene nanosheets by a solvothermal method, followed by the modification of $\mathrm{Nb}_{2} \mathrm{C}$ QDs with the thiol group (Fig. 1a). Given the self-assembling effect between the $\mathrm{Nb}_{2} \mathrm{C}-\mathrm{SH}$ QDs and the Au chip of SPR, $\mathrm{Nb}_{2} \mathrm{C}-\mathrm{SH}$ QDs were homogeneously coated over the chip surface, and the N58 aptamer was stably immobilized through $\pi-\pi^{*}$ stacking, electrostatic adsorption, and hydrogen bond [54]. In the presence of SARS-CoV-2, the G-quadruplex between the N58 aptamer and N-gene of SARS-CoV-2 was formed [55]. Thus, the aptamer strands changed its conformation [56] when binding with $\mathrm{N}$-gene, leading to the enlargement of the contact area or distance between the probe molecule and the chip. These modifications were then converted to change in the SPR signal to detect N-gene of SARS-CoV-2 (Fig. 1b). Compared with previously reported SPR biosensors for the same detection [11], the SPR aptasensor based on the $\mathrm{Nb}_{2} \mathrm{C}$ SH QDs exhibited superior sensing performances, such as high sensitivity, fast response, renewability, and availability in complex environments. These advantages are mainly ascribed to several factors. The multifunctional properties of $\mathrm{Nb}_{2} \mathrm{C}$-SH QDs not only can ensure homogeneously deposition onto the SPR chip but also can tightly adsorb a large amount of aptamers, further resulting in high sensitivity. The highly specific recognition between N58 aptamer and N-gene endows the SPR aptasensor with a fast response toward Ngene. In addition, the $\mathrm{Nb}_{2} \mathrm{C}$-SH QD-based SPR biosensor can be widely applied for detecting N-gene from diverse environments, such as human serum, seawater, and seafood, because of its easy construction, high stability, and good renewability. Thereby, the present work provides a new insight into the development of the SPR aptasensor for the fast and sensitive analysis of N-gene of SARS-CoV-2 from different real samples. 


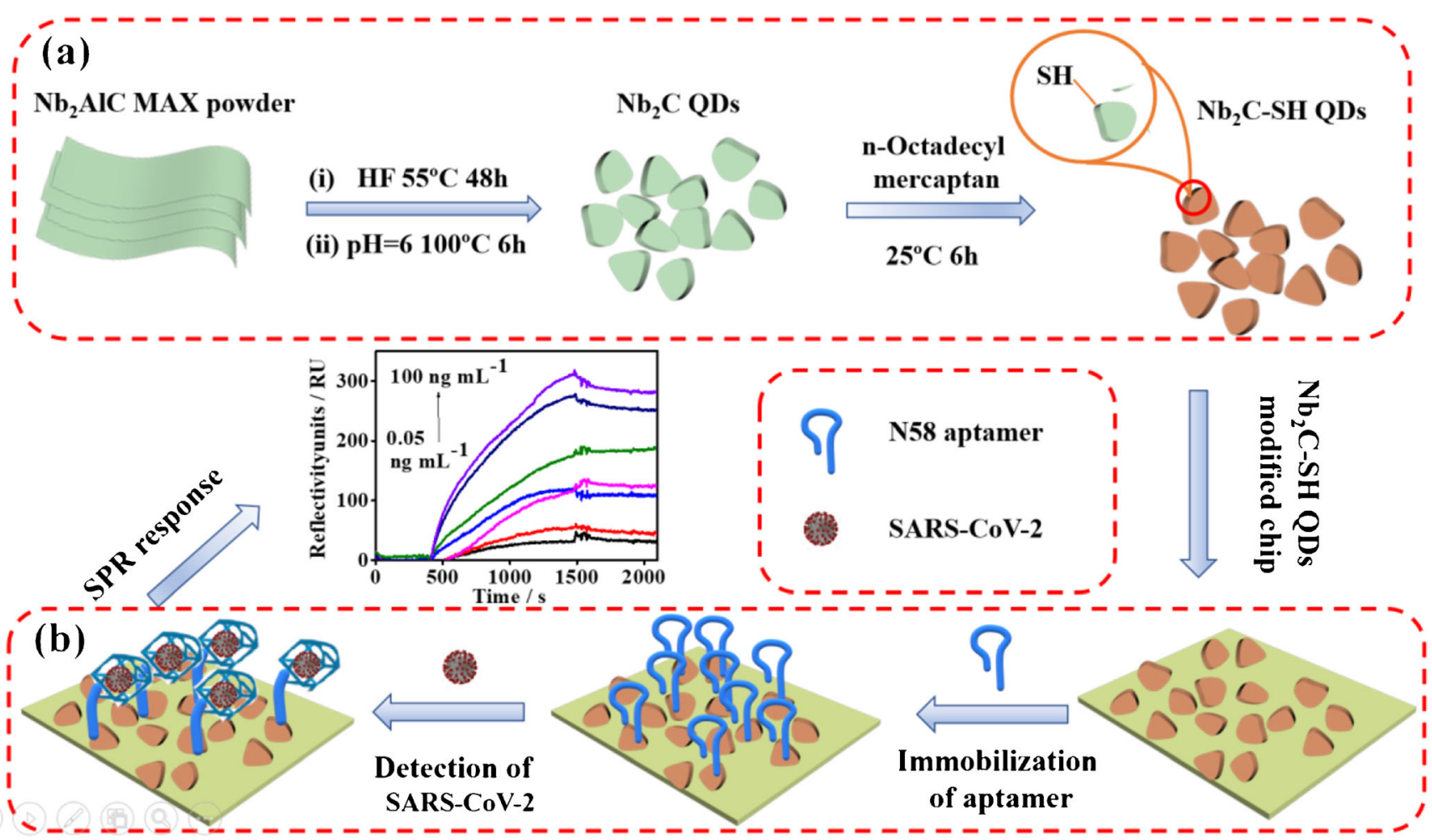

Fig. 1 Schematic diagram of a the synthesis of $\mathrm{Nb}_{2} \mathrm{C}-\mathrm{SH}$ QDs and $\mathbf{b}$ construction of the $\mathrm{Nb}_{2} \mathrm{C}-\mathrm{SH}$ QD-based SPR aptasensor for detecting $\mathrm{N}$-gene of SARS-CoV-2

\section{Experimental section}

\section{Chemicals and materials}

Bulk $\mathrm{Nb}_{2} \mathrm{AlC}$ powder, hydrofluoric acid (HF), dimethyl sulfoxide (DMSO), $N, N$-dimethylformamide (DMF), and $n$ octadecyl mercaptan were purchased from Aladdin Reagent Co. Ltd. Biologicals including influenza A virus (Flu A), influenza B virus (Flu B), M. pneumonia (P1), chlamydia pneumoniae (CPN), immunoglobulin (IgG), prostate-specific antigen (PSA), bovine albumin (BSA), and SARS-CoV-2 and SARS-CoV-2-N58 aptamer sequence: 5'-GCT GGA TGT CAC CGG ATT GTC GGA CAT CGG ATT GTC TGA GTC ATA TGA CAC ATC CAG C-3' were ordered from Solarbio Life Sciences Co. Ltd. Additionally, human serum was obtained from the First Affiliated Hospital of Zhengzhou University after informed consent of the patient. This research protocol was in accordance with the ethical standards of the 1964 Declaration of Helsinki and its subsequent revisions and was approved by the ethics committee of the First Affiliated Hospital of Zhengzhou University.

\section{Preparation of $\mathrm{Nb}_{2} \mathrm{C}$ QDs and $\mathrm{Nb}_{2} \mathrm{C}-\mathrm{SH}$ QDs}

The preparation of the $\mathrm{Nb}_{2} \mathrm{C}$ QDs was realized through a solvothermal method according to the reported literature [57]. The detailed preparation methods of the $\mathrm{Nb}_{2} \mathrm{C}$ QDs and $\mathrm{Nb}_{2} \mathrm{C}-\mathrm{SH}$ QDs were described in the Electronic Supplementary Material.

\section{SPR measurements}

All SPR measurements were performed by a Biacore ${ }^{\mathrm{TM}} \mathrm{X} 100$ device (GE-Healthcare Bio-Sciences AB, Sweden, the wavelength of the laser (He-Ne) of $633 \mathrm{~nm})$ at $25{ }^{\circ} \mathrm{C}$ with flowing $0.01 \mathrm{M}$ phosphate buffer saline (PBS) $(\mathrm{pH}=7.4)$ containing $2.7 \mathrm{mM} \mathrm{KCl}, 137 \mathrm{mM} \mathrm{NaCl}$, and $0.5 \%$ DMSO. In prior to use, the work chip, a standard $10 \times 12 \times 0.3 \mathrm{~mm}$ glass chip coated with gold film $(\sim 50 \mathrm{~nm})$, was cleaned with $\mathrm{H}_{2} \mathrm{SO}_{4} /$ $\mathrm{H}_{2} \mathrm{O}_{2}(70 / 30 \mathrm{v} / \mathrm{v})$ for $1 \mathrm{~min}$, following by washing with Milli-Q water and drying in $\mathrm{N}_{2}$ stream. Afterwards, $10 \mu \mathrm{L}$ of $\mathrm{Nb}_{2} \mathrm{C}$-SH QDs suspension $\left(0.1 \mathrm{mg} \mathrm{mL} \mathrm{m}^{-1}\right)$ was dropped on the gold chip surface, forming the homogeneous $\mathrm{Nb}_{2} \mathrm{C}$ QDs layer via the covalent bond of $\mathrm{Au}-\mathrm{S}$ between thiol group bearing on $\mathrm{Nb}_{2} \mathrm{C}$-SH QDs and gold atom by the selfassembling interaction [58]. Equilibration of the baseline was completed by a continuous flow $\left(5 \mu \mathrm{L} \mathrm{min}^{-1}\right)$ of running buffer through the chip for $0.5 \mathrm{~h}$. Afterward, the $\mathrm{Nb}_{2} \mathrm{C}-\mathrm{SH}$ QDs-modified gold chip was incubated with the aptamer immobilization $(100 \mathrm{nM})$ at a flow rate of $5 \mu \mathrm{L} \mathrm{min}{ }^{-1}$ for $0.5 \mathrm{~h}$. After obtaining a stable baseline, the SPR flow cell was washed with running buffer to remove the unbounded aptamer. Each binding experiment for the detection of Ngene was dissolved in PBS at predetermined concentrations 
$\left(0.05,0.1,1,5,10,50\right.$, and $\left.100 \mathrm{ng} \mathrm{mL}^{-1}\right)$ and introduced into the flow cell at a flow rate of $5 \mu \mathrm{L} \mathrm{min}{ }^{-1}$. The specificity analysis of the SPR aptasensor was performed by injecting several kinds of interferents, which may be coexisted with N-gene of SARS-CoV-2, including Flu A, Flu B, P1, CPN, $\mathrm{IgG}$, PSA, and BSA, respectively, at a flow rate of $5 \mu \mathrm{L} \mathrm{min}{ }^{-1}$. The loading of the SPR chip was calculated considering one reflectivity unit (RU) corresponding to a change in refractive of $10^{-6}$ and approximately $1 \mathrm{pg} \mathrm{mm}^{-2}$ of bound protein.

\section{Real samples}

For the analysis of real samples, human serum without pretreatment was firstly spiked with different amounts of SARSCoV-2 N-gene. Afterward, human serum was diluted 10 times with PBS. Sea water was obtained from the Yellow Sea. Different amounts of N-gene of SARS-CoV-2 were added to sea water. In addition, seafood was purchased from seafood market in Zhengzhou and treated according to a previous report [59]. After being spiked with different amounts N-gene of SARS-CoV-2, $2 \mathrm{~g}$ of shrimp was added to $4 \mathrm{~mL}$ of $3 \%$ trichloroacetic acid (TA) under stirring for $10 \mathrm{~min}$. Next, the resulting extract was centrifuged at $12,000 \mathrm{rpm}$ for $10 \mathrm{~min}$. Moreover, the $\mathrm{pH}$ value of supernatant was then adjusted to 7 with $1.0 \mathrm{M} \mathrm{NaOH}$, following by diluted 100 -fold with deionized water.

\section{Results and discussion}

\section{Basic characterizations of $\mathrm{Nb}_{2} \mathrm{C}-\mathrm{SH}$ QDs}

Transmission electron microscopy (TEM) was performed to characterize the microstructure and morphological characteristics of $\mathrm{Nb}_{2} \mathrm{C}-\mathrm{SH}$ QDs (Fig. 2a-c). The QDs are clearly observed in the low-magnification TEM image of $\mathrm{Nb}_{2} \mathrm{C}-\mathrm{SH}$ QDs (Fig. 2a), which have average lateral sizes from 2.3 to $5.4 \mathrm{~nm}$ (Fig. 2b). The inset image in Fig. 2a depicts the corresponding size distribution curve. A clear fringe is obtained in the high-resolution TEM image of the $\mathrm{Nb}_{2} \mathrm{C}-\mathrm{SH}$ QDs (Fig. $2 \mathrm{c}$ ), indicating the single-crystalline feature of the $\mathrm{Nb}_{2} \mathrm{C}-\mathrm{SH}$ QDs. The distance between adjacent lattice fringes is $0.217 \mathrm{~nm}$, which well matches with the [001] direction plane of graphene carbon [60].

Fourier transform infrared spectra (FT-IR) of the $\mathrm{Nb}_{2} \mathrm{C}$ QDs and $\mathrm{Nb}_{2} \mathrm{C}$-SH QDs were shown in Fig. S1 (see the Electronic Supplementary Material), indicating that a sufficient number of oxygen-bearing functional groups are decorated on both QDs. To further evaluate the chemical structure and component of the $\mathrm{Nb}_{2} \mathrm{C}$ QDs and $\mathrm{Nb}_{2} \mathrm{C}$-SH QDs, X-ray photoelectron spectroscopy (XPS) characterization was performed. The XPS survey spectrum of the $\mathrm{Nb}_{2} \mathrm{C}$ QDs (curve i, Fig. S2) indicates four peaks at the binding energies (BEs) of 286.1, 532.1, 407.1, and $232.1 \mathrm{eV}$, which are assigned to $\mathrm{C} 1 s$, $\mathrm{O} 1 s, \mathrm{~N} 1 s$, and $\mathrm{Nb} 3 d$, respectively. For $\mathrm{Nb}_{2} \mathrm{C}-\mathrm{SH}$ QDs, an additional signal due to $\mathrm{S} 2 p$ at the $\mathrm{BE}$ of $168.1 \mathrm{eV}$ is obtained (curve ii, Fig. S2). To further probe the chemical environments and valence states of each element, the highresolution $\mathrm{C} 1 s, \mathrm{Nb} 3 d$, and $\mathrm{N} 1 s$ XPS spectrum of the $\mathrm{Nb}_{2} \mathrm{C}$ QDs and $\mathrm{Nb}_{2} \mathrm{C}-\mathrm{SH}$ QDs were analyzed (Fig. 2d-f). The highresolution $\mathrm{C} 1 s$ spectrum (Fig. 2 (d1)) of $\mathrm{Nb}_{2} \mathrm{C}$ QDs can be deconvoluted into three peaks at BEs of 284.5, 285.5, and $287.4 \mathrm{eV}$, which are attributed to graphitic $\mathrm{C}-\mathrm{C}, \mathrm{C}-\mathrm{N}$, and $\mathrm{O}=\mathrm{C}-\mathrm{N}$, respectively. The presence of $\mathrm{O}=\mathrm{C}-\mathrm{N}$ indicates that the $\mathrm{Nb}_{2} \mathrm{C}$ QDs are slightly oxidized during the preparation. The high-resolution $\mathrm{Nb} 3 d$ XPS spectrum of $\mathrm{Nb}_{2} \mathrm{C}$ QDs (Fig. 2 (e1)) is fitted by two peaks at 207.3 and $210 \mathrm{eV}$, which are assigned to the BEs of $\mathrm{Nb} 3 d_{5 / 2}$ and $\mathrm{Nb} 3 d_{3 / 2}$ of $\mathrm{Nb}^{5+}$, respectively. This finding reveals that the $\mathrm{Nb}_{2} \mathrm{C}$ phase is substantially oxidized $[61,62]$. The high-resolution $\mathrm{N} 1 s$ spectrum of the $\mathrm{Nb}_{2} \mathrm{C}$ QDs (Fig. 2 (f1)) has been commonly simulated with two peaks at the BEs of 399.8 and $402.1 \mathrm{eV}$, corresponding to pyridinic $\mathrm{N}$ and quaternary $\mathrm{N}$ [63]. Compared with the $\mathrm{C} 1 s \mathrm{X}$-ray photoelectron spectrum of $\mathrm{Nb}_{2} \mathrm{C}$ QDs, an additional peak at the $\mathrm{BE}$ of $285 \mathrm{eV}$ due to $\mathrm{C}$-S bond appears in the $\mathrm{C} 1 s \mathrm{X}$-ray photoelectron spectrum of the $\mathrm{Nb}_{2} \mathrm{C}$ QDs-SH (Fig. 2 (d2)). This peak is caused by the modified thiol group. No clear change is observed for the $\mathrm{Nb}$ $3 d$ and $\mathrm{N} 1 s$ X-ray photoelectron spectra of the $\mathrm{Nb}_{2} \mathrm{C}-\mathrm{SH}$ QDs compared with that of $\mathrm{Nb}_{2} \mathrm{C}$ QDs but with lower peak intensity. A discernable observation of the $\mathrm{N}$-species is that the conversion from pyrrolic $\mathrm{N}$ to graphitic $\mathrm{N}$ occurs upon the additional doping of $\mathrm{S}$ into the $\mathrm{Nb}_{2} \mathrm{C}$ QDs [64]. Moreover, the $\mathrm{S} 2 p$ XPS spectrum of $\mathrm{Nb}_{2} \mathrm{C}-\mathrm{SH}$ QDs (Fig. S3) is analyzed in Section S3 of the Electronic Supplementary Material. These results verify the coverage of the self-assembling layer over the $\mathrm{Nb}_{2} \mathrm{C}$ QDs.

In prior to the SPR measurements, XPS was used to investigate whether the N-58-targeted aptamer can be immobilized over the $\mathrm{Nb}_{2} \mathrm{C}$ QDs-modified Au chip. For the C $1 s \mathrm{X}$-ray photoelectron spectrum of the $\mathrm{Apt}_{\mathrm{N}-58}$ aptamer $/ \mathrm{Nb}_{2} \mathrm{C}-\mathrm{SH}$ QDs (Fig. 2 (d3)), the two peaks at the BEs of 285.0 and $285.9 \mathrm{eV}$, which are due to $\mathrm{C}-\mathrm{S}$ and $\mathrm{C}-\mathrm{O}$, respectively, are deconvoluted. The $\mathrm{C}-\mathrm{O}$ bond is caused by the immobilized aptamer strands. In addition, no clear Nd $3 d$ XPS signal is present in the $\mathrm{Apt}_{\mathrm{N}}$ 58 aptamer $/ \mathrm{Nb}_{2} \mathrm{C}$-SH QDs (Fig. 2 (e3)), indicating that the full coverage of the aptamer strands over the modified layer. The $\mathrm{N} 1 s$ X-ray photoelectron spectrum of the $\mathrm{Apt}_{\mathrm{N}-58 \text { aptamer }}$ / $\mathrm{Nb}_{2} \mathrm{C}$ QDs can be fitted to two peaks at the BEs of 399.7 and $401.7 \mathrm{eV}$, which are attributed to pyridinic-N and graphitic N, respectively [65]. As an indicator of the aptamer strands, the P $2 p$ XPS signal was obtained in the XPS survey scan spectrum of the $\mathrm{Apt}_{\mathrm{N}-58}$ aptamer $/ \mathrm{Nb}_{2} \mathrm{C}-\mathrm{SH}$ QDs. The highresolution P $2 p$ XPS spectrum (Fig. S4) can be separated into two peaks at the BEs of 132.9 and $133.9 \mathrm{eV}$, which are due to 
Fig. 2 a Low-magnification, b high-magnification, and $\mathbf{c}$ highresolution TEM images (the inset images show the corresponding size distribution curves) of the $\mathrm{Nb}_{2} \mathrm{C}$ QDs. High-resolution $\mathrm{C} 1 s$, $\mathrm{Nb} 3 d$, and $\mathrm{N} 1 s$ XPS spectra of (d1, e1, and f1) $\mathrm{Nb}_{2} \mathrm{C}$ QDs, (d2, e2, and f2) $\mathrm{Nb}_{2} \mathrm{C}-\mathrm{SH}$ QDs and (d3, e3, and f3) Apt $/ \mathrm{Nb}_{2} \mathrm{C}-\mathrm{SH}$ QDs
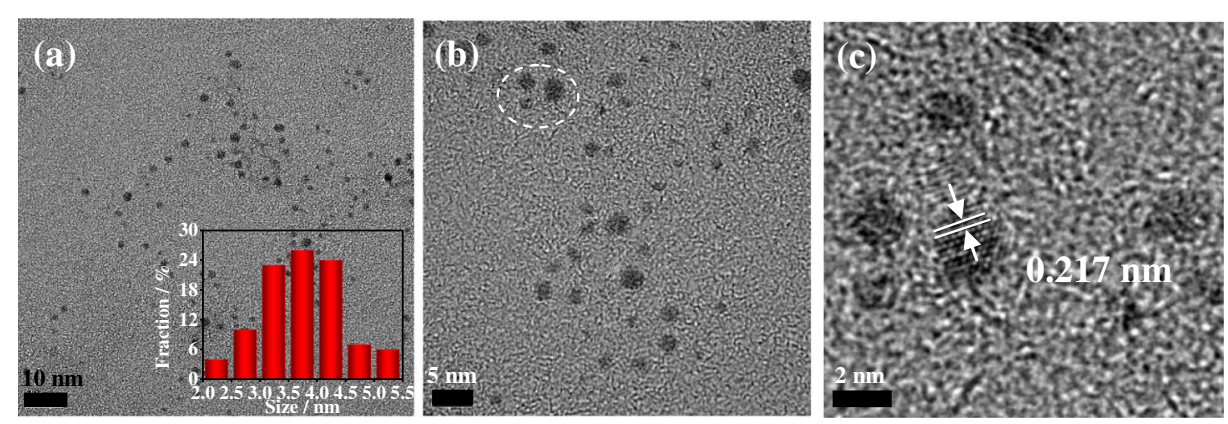

:

(d) $\mathrm{C} 1 \mathrm{~s}$

(e) $\mathrm{Nb} 3 \mathrm{~d}$

(f) $\mathrm{N} 1 s$

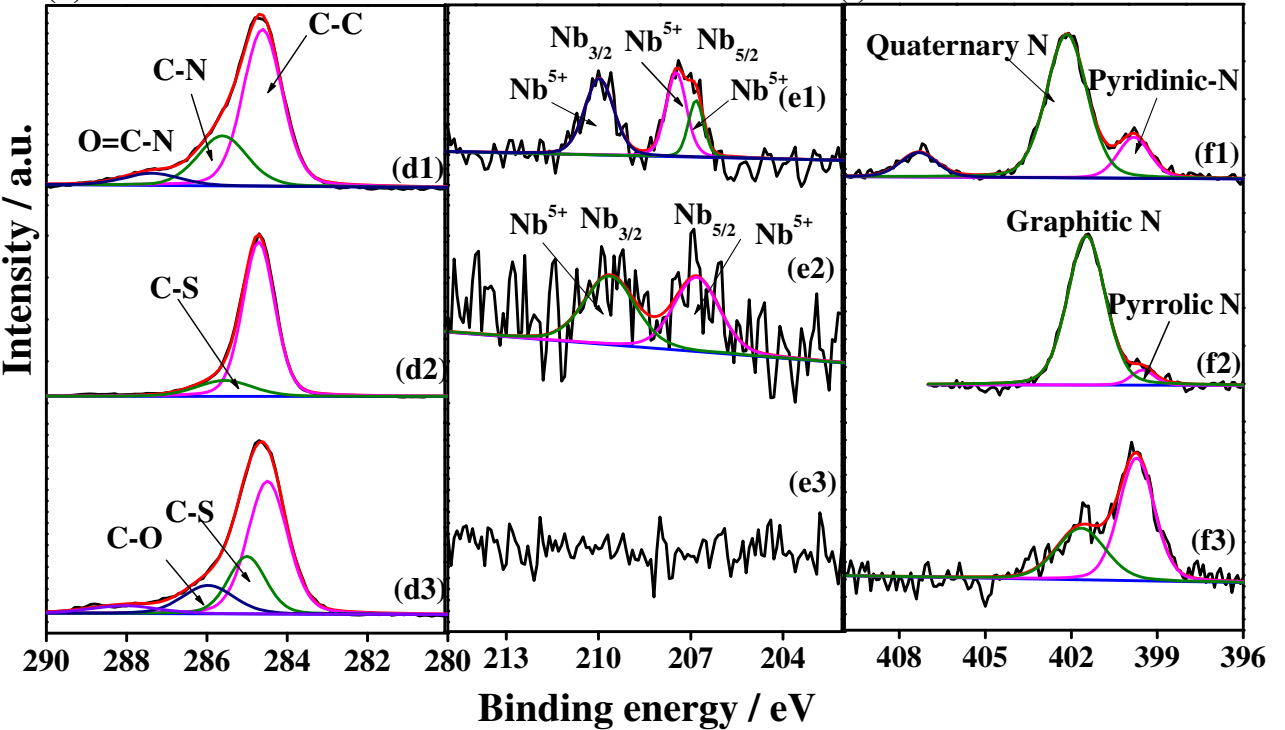

$\mathrm{P} 2 p_{3 / 2}$ and $\mathrm{P} 2 p_{1 / 2}$, respectively. Apparently, the clear $\mathrm{P} 2 p$ XPS signal is from the phosphate backbone of the N 58 aptamer [66].

The optical properties of $\mathrm{Nb}_{2} \mathrm{C}$-SH QDs were studied by UV-vis spectrum and fluorescence spectroscopy (Fig. S5). The results and analysis are supplied in Section S4 of the Electronic Supplementary Material.

\section{Sensing performance of the $\mathrm{Nb}_{2} \mathrm{C}$-SH QD-based aptasensor toward $\mathrm{N}$-gene}

Ahead of investigating the optimization of the determination conditions, the electrochemical surface area (ECSA) of the aptasensor was calculated from corresponding CVs (Fig. S6). The ECSA of the aptasensor is $10.5 \mathrm{~cm}^{2}$, revealing good electrochemical activity. In prior to the analysis of $\mathrm{N}$-gene by using the $\mathrm{Nb}_{2} \mathrm{C}$-SH QD-based aptasensor, the determination conditions or parameters, including the concentration of aptamer, $\mathrm{pH}$ value of PBS, and the concentration of $\mathrm{Nb}_{2} \mathrm{C}$ SH QDs, were investigated to obtain the optimal sensing performance of the $\mathrm{Nb}_{2} \mathrm{C}$-SH QD-based SPR aptasensor. The results (Fig. S7) and analysis are supplied in Section S6 of the Electronic Supplementary Material. The optimal conditions for the construction of the $\mathrm{Nb}_{2} \mathrm{C}-\mathrm{SH}$ QD-based aptasensor are aptamer solution concentration of $100 \mathrm{nM}$, $0.01 \mathrm{M}$ PBS with $\mathrm{pH} 7.4$, and the $\mathrm{Nb}_{2} \mathrm{C}-\mathrm{SH}$ QDs concentration of $1 \mathrm{mg} \mathrm{mL}^{-1}$.

Under the optimal detection conditions, the sensing performance of the $\mathrm{Nb}_{2} \mathrm{C}$-SH QD-based aptasensor toward $\mathrm{N}$-gene was probed. The $\mathrm{Nb}_{2} \mathrm{C}-\mathrm{SH} \mathrm{QD}$-coated Au chip was incubated with different concentrations of $\mathrm{N}$-gene and measured by the SPR instrument (Fig. 3a). The SPR response gradually increases from 40 to 270 RU with increasing N-gene concentration from 0.05 to $100 \mathrm{ng} \mathrm{mL}^{-1}$ within $1000 \mathrm{~s}$ (Fig. 3b). As aforementioned, the N58 aptamer strands would bind with Ngene of SARS-CoV-2, specifically forming the G-quadruplex between the aptamer and N-gene. This characteristic further increases the thickness of the Au chip for the SPR biosensor, which can vary the refractive index of the overlayer [67]. After $1000 \mathrm{~s}$, the $\mathrm{Nb}_{2} \mathrm{C}-\mathrm{SH}$ QD-based SPR aptasensor was rinsed with $0.01 \mathrm{M}$ PBS. The resulting decrease in the SPR response is $\sim 15 \mathrm{RU}$, which is considerably low. This finding indicates the strong binding interaction between $\mathrm{N}$-gene and aptamer strands. When $\Delta \mathrm{RU}$ of the $\mathrm{Nb}_{2} \mathrm{C}-\mathrm{SH}$ QD-based SPR aptasensor before and after the detection of $\mathrm{N}$-gene $(\Delta \mathrm{RU}=$ $\left.R U_{\mathrm{N} \text {-gene }}-\mathrm{RU}_{\mathrm{Apt}}\right)$ is defined as the detected signal, the $\Delta \mathrm{RU}$ value is proportional to the logarithm value of $\mathrm{N}$-gene con-

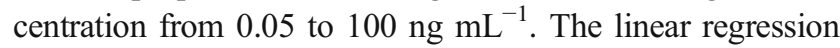


Fig. 3 a SPR aptasensor responses of the $\mathrm{Apt}_{\mathrm{N} 58} /$ $\mathrm{Nb}_{2} \mathrm{CQDs} / \mathrm{Au}$ with different concentrations of $\mathrm{N}$-gene $(0.05$, $0.1,1,5,10,50$, and $100 \mathrm{ng} \mathrm{mL}^{-1}$ ). b Relationship between the $\Delta R U$ values $(\Delta R U=$ $\mathrm{RU}_{\mathrm{N} \text {-gene }}-\mathrm{RU}_{\mathrm{N} 58 \text { aptamer }}$ ) and Ngene concentration. Inset: Linear relationship between $\Delta \mathrm{RU}$ and logarithm of $\mathrm{Nb}_{2} \mathrm{C}$-SH QDs concentration. c Selectivity of the $\mathrm{Nb}_{2} \mathrm{C}$-SH QD-based SPR aptasensor for $\mathrm{N}$-gene detection $\left(1 \mathrm{ng} \mathrm{mL}^{-1}\right)$ in the presence of CPN, flu A, Flu B, P1, IgG, PSA, and BSA (100 $\mathrm{n} \mathrm{mL}^{-1}$ ) (a)

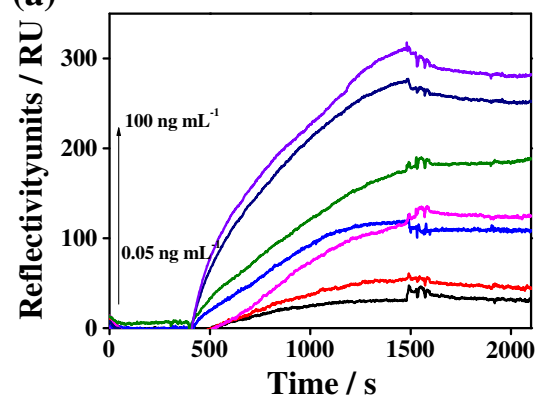

(b)

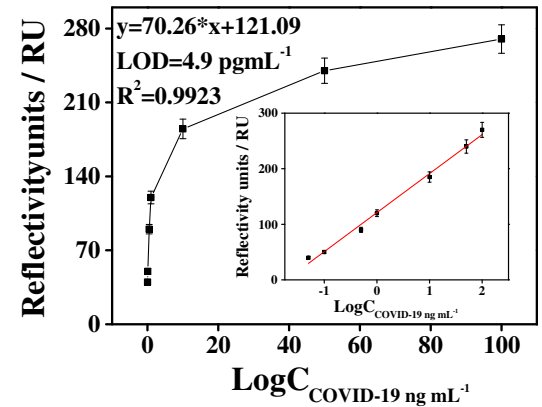

(c)

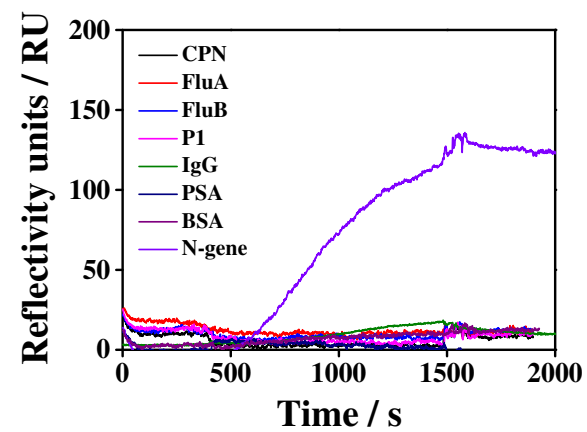

equation was $\Delta \mathrm{RU}=70.26 \log \mathrm{C}_{\mathrm{N} \text {-gene }}+121.09$, with the correlation coefficient $\left(R^{2}\right)$ of 0.9923 (the inset of Fig. 3b). The detection limit (LOD) was estimated to be as low as $4.9 \mathrm{pg} \mathrm{mL}^{-1}$ at a signal-to-noise ratio of 3 [68]. The LOD was calculated with the equation $\left(\mathrm{LOD}=3.3 S_{B} / \mathrm{m}\right)$ derived from the criterion of the IUPAC recommendation, where $S_{B}$ refers to the standard deviation of the blank $(n=3)$, and $\mathrm{m}$ refers to the slope of the linear calibration curve [69]. Compared with the reported SPR, optical, or electrochemical aptasensors for analyzing N-gene of SARS-CoV-2 (Table S1), the SPR aptasensor based on $\mathrm{Nb}_{2} \mathrm{C}-\mathrm{SH}$ QDs demonstrates lower LOD and faster response. The low LOD and fast response toward $\mathrm{N}$-gene by using the $\mathrm{Nb}_{2} \mathrm{C}$-SH QDs-based aptasensor is mainly due to several aspects. (i) The strong self-assembling interaction between thiol bearing on the $\mathrm{Nb}_{2} \mathrm{C}-\mathrm{SH} \mathrm{QDs}$ and Au chip surface provides the outstanding stability of the aptasensor in the aqueous solution [70]. (ii) The strong bioaffinity between the aptamer and highly conjugated $\mathrm{Nb}_{2} \mathrm{C}-\mathrm{SH}$ QDs via $\pi-\pi^{*}$ stacking, hydrogen bonds, and Van der Waal force facilitates the full coverage of the aptamer onto the $\mathrm{Nb}_{2} \mathrm{C}$-SH QD-modified Au chip, leading to the high detection efficiency toward N-gene [71]. (iii) The highly specific recognition between aptamer and $\mathrm{N}$-gene can reduce the nonspecific adsorption of other interferents on the $\mathrm{Nb}_{2} \mathrm{C}-\mathrm{SH}$ QDbased biosensor [72]. No substantial $\Delta R U$ change is found for the BSA adsorption, hinting the absence of a strong nonspecific binding (Fig. S8).

The selectivity of the constructed $\mathrm{Nb}_{2} \mathrm{C}-\mathrm{SH}$ QD-based aptasensor was also examined by analyzing different

interferents, including other kinds of respiratory viruses (i.e., Flu A, Flu B, P1, and CPN) and proteins in the human serum (i.e., IgG, PSA, and BSA), with the concentration of $100 \mathrm{ng} \mathrm{mL} \mathrm{mL}^{-1}$, which was 100 -fold of the used $\mathrm{N}$-gene concentration. The $\Delta \mathrm{RU}$ values for each interferent and the detection of $\mathrm{N}$-gene are shown in Fig. 3c. The result indicates that the $\Delta R U$ value obtained from the analysis of the interferents is negligible, greatly lower than that of the $\mathrm{Nb}_{2} \mathrm{C}-\mathrm{SH}$ QD-based $\mathrm{SPR}$ response of $\mathrm{N}$-gene. This finding suggests that the $\mathrm{Nb}_{2} \mathrm{C}-\mathrm{SH}$ QD-based aptasensor has the outstanding selectivity for analyzing $\mathrm{N}$-gene.

\section{Determination of $\mathrm{N}$-gene in different environments and human serum}

Given that the $\mathrm{Nb}_{2} \mathrm{C}$-SH QD-based aptasensor displays high sensitivity and good selectivity, the aptasensor can be employed to detect $\mathrm{N}$-gene in diverse environments, such as in seawater, seafood (frozen shrimp), and human serum, to verify the suitability of the aptasensor. The pretreatment procedure of each sample is provided in the Real samples of the Experimental section. The original concentration of the target analyte (before the sample being spiked) in the real samples was also investigated. The result (Fig. S9) shows that the $\Delta \mathrm{RU}$ of the $\mathrm{Nb}_{2} \mathrm{C}-\mathrm{SH}$ QD-based SPR aptasensor before and after the detection of $\mathrm{N}$-gene in seawater, seafood, and human serum is negligible. This finding verifies that no 
Table 1 Analysis of $\mathrm{N}$-gene in seawater using the $\mathrm{Nb}_{2} \mathrm{C}-\mathrm{SH}$ QDbased aptasensor

\begin{tabular}{|c|c|c|c|c|c|}
\hline 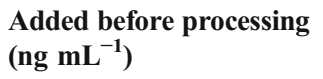 & $\begin{array}{l}\text { Actual added } \\
\left(\text { ng mL } \mathrm{mL}^{-1}\right)\end{array}$ & $\Delta \mathbf{R U}$ & $\begin{array}{l}\text { Found } \\
\left(\text { ng } \mathrm{mL}^{-1}\right)\end{array}$ & $\begin{array}{l}\text { Apparent } \\
\text { recovery }(\%)\end{array}$ & $\begin{array}{l}\text { RSD } \\
(\%)\end{array}$ \\
\hline 0.05 & 0.05 & 29.50 & 0.0497 & 99.40 & 2.13 \\
\hline 0.1 & 0.1 & 54.10 & 0.1113 & 111.30 & 1.98 \\
\hline 1 & 1 & 121.00 & 0.9970 & 99.70 & 2.26 \\
\hline 10 & 10 & 192.00 & 10.216 & 102.16 & 1.04 \\
\hline 100 & 100 & 260.90 & 97.700 & 97.70 & 2.79 \\
\hline
\end{tabular}

Table 2 Analysis of $\mathrm{N}$-gene in seafood using the $\mathrm{Nb}_{2} \mathrm{C}$-SH QDbased aptasensor

\begin{tabular}{|c|c|c|c|c|c|}
\hline $\begin{array}{l}\text { Added before processing } \\
\left(\mathrm{ng} \mathrm{mL} \mathrm{L}^{-1}\right)\end{array}$ & $\begin{array}{l}\text { Actual added } \\
\left(\mathrm{ng} \mathrm{mL^{-1 }}\right)\end{array}$ & $\Delta \mathbf{R U}$ & $\begin{array}{l}\text { Found } \\
\left(\text { ng } \mathbf{m L}^{-1}\right)\end{array}$ & $\begin{array}{l}\text { Apparent } \\
\text { recovery (\%) }\end{array}$ & $\begin{array}{l}\text { RSD } \\
(\%)\end{array}$ \\
\hline 5 & 0.05 & 27.10 & 0.0459 & 91.80 & 3.34 \\
\hline 10 & 0.1 & 48.90 & 0.0938 & 93.80 & 2.79 \\
\hline 100 & 1 & 119.60 & 0.9523 & 95.23 & 2.07 \\
\hline 1000 & 10 & 190.06 & 9.5860 & 95.86 & 1.99 \\
\hline 10,000 & 100 & 259.30 & 92.709 & 92.71 & 4.21 \\
\hline
\end{tabular}

$\mathrm{N}$-gene exists in real samples. Consequently, the applicability of the developed aptasensor can be assessed by spiking a series of $\mathrm{N}$-gene solutions with different concentrations into real samples. Different concentrations of $\mathrm{N}$-gene were spiked into diverse samples. Then, the determination using the $\mathrm{Nb}_{2} \mathrm{C}-\mathrm{SH}$ QD-based aptasensor was carried out as described in previous sections. According to the calibration curve, the real concentrations of $\mathrm{N}$-gene were deduced. All results are summarized in Tables 1, 2, and 3. As indicated in Table 1, the recoveries for detecting $\mathrm{N}$-gene in seawater range from 97.70 to $111.30 \%$, along with low RSD values of 1.04$2.79 \%$. For N-gene in seafood (Table 2), the found recoveries are from 91.80 to $95.86 \%$, while they are ranging from 98.67 to $104.86 \%$ in the human serum (Table 3 ). The corresponding RSD values are 1.99$4.21 \%$ and $1.76-4.12 \%$. These results verify that the $\mathrm{Nb}_{2} \mathrm{C}-\mathrm{SH}$ QD-based aptasensor can be utilized to analyze $\mathrm{N}$-gene from different environments.

\section{Conclusion}

A novel SPR aptasensor was designed and constructed by using $\mathrm{Nb}_{2} \mathrm{C}-\mathrm{SH}$ QDs as the sensitive layer for anchoring $\mathrm{N}$ gene-targeted aptamer strands, which were used for the specific determination of N-gene of SARS-CoV-2. Given the thiol-functionalized, highly conjugated structure, and graphene-like MXene phase, the prepared $\mathrm{Nb}_{2} \mathrm{C}-\mathrm{SH}$ QDs not only displayed high binding interaction with the Au chip via the self-assembling force by forming $\mathrm{Au}-\mathrm{S}$ bond but also demonstrated strong bioaffinity toward the aptamer strands, and the amplified SPR effect. Apart from low detection limit within a wide linear range of $\mathrm{N}$-gene concentration, high selectivity, excellent repeatability exhibits, and good applicability, the provided SPR aptasensor based on $\mathrm{Nb}_{2} \mathrm{C}-\mathrm{SH}$ QDs apparently demonstrates the advantage of feasible construction, fast response, and in situ analysis. This work paves the way for the fabrication of $\mathrm{N}$-gene aptasensor and provides a new sensing strategy for the early and sensitive analysis of $\mathrm{N}$ -
Table 3 Analysis of $\mathrm{N}$-gene in human serum using the $\mathrm{Nb}_{2} \mathrm{C}-\mathrm{SH}$ QD-based aptasensor

\begin{tabular}{|c|c|c|c|c|c|}
\hline $\begin{array}{l}\text { Added before processing } \\
\left(\text { ng } \mathrm{mL}^{-1}\right)\end{array}$ & $\begin{array}{l}\text { Actual added } \\
\left(\text { ng mL } \mathrm{mL}^{-1}\right)\end{array}$ & $\Delta \mathbf{R} \mathbf{U}$ & $\begin{array}{l}\text { Found } \\
\left(\text { ng mL } \mathbf{m L}^{-1}\right)\end{array}$ & $\begin{array}{l}\text { Apparent } \\
\text { recovery }(\%)\end{array}$ & $\begin{array}{l}\text { RSD } \\
(\%)\end{array}$ \\
\hline 0.5 & 0.05 & 29.60 & 0.0498 & 99.60 & 4.12 \\
\hline 1 & 0.1 & 52.00 & 0.1039 & 103.90 & 2.37 \\
\hline 10 & 1 & 120.90 & 0.9937 & 99.37 & 2.49 \\
\hline 100 & 10 & 192.80 & 10.486 & 104.86 & 1.76 \\
\hline 1000 & 100 & 261.20 & 98.665 & 98.67 & 3.22 \\
\hline
\end{tabular}


gene. Nonetheless, the $\mathrm{Nb}_{2} \mathrm{C}$ QDs-based SPR aptasensor still exhibits some unsatisfied features such as poor repeatability and regenerability when detecting $\mathrm{N}$-gene.

Supplementary Information The online version contains supplementary material available at https://doi.org/10.1007/s00604-021-04974-z.

Funding This work was supported by the Excellent Youth Science Foundation of Henan Province (202300410494), the Distinguished Youth Science Foundation of Henan Province (No. 202300410492), and Innovative Technology Team of Henan Province (CXTD2014042).

\section{Compliance with ethical standards}

Conflict of interest The authors declare that they have no competing interests.

\section{References}

1. Parashar NC, Poddar J, Chakrabarti S, Parashar G (2020) Repurposing of SARS-CoV nucleocapsid protein specific nuclease resistant RNA aptamer for therapeutics against SARS-CoV-2. Infect Genet Evol 85:104497

2. Kolodny O, Berger M, Feldman MW, Ram Y (2020) A new perspective for mitigation of SARS-CoV-2 infection: priming the innate immune system for viral attack. Open Biol 10:200138

3. Liu P, Yang M, Zhao X, Guo Y, Wang L, Zhang J, Lei W, Han W, Jiang F, Liu WJ, Gao GF, Wu G (2020) Cold-chain transportation in the frozen food industry may have caused a recurrence of COVID-19 cases in destination: successful isolation of SARS$\mathrm{CoV}-2$ virus from the imported frozen cod package surface. Biosafety Health 2:199-201

4. Mohapatra S, Menon NG, Mohapatra G, Pisharody L, Pattnaik A, Menon NG, Bhukya PL, Srivastava M, Singh M, Barman MK, Gin KY, Mukherji S (2021) The novel SARS-CoV-2 pandemic: possible environmental transmission, detection, persistence and fate during wastewater and water treatment. Sci Total Environ 765:142746

5. Alkhansa A, Lakkis G, El Zein L (2021) Mutational analysis of SARS-CoV-2 ORF8 during six months of COVID-19 pandemic. Gene Rep 23:101024

6. Fabiani L, Saroglia M, Galatà G, De Santis R, Fillo S, Luca V, Faggioni G, D'Amore N, Regalbuto E, Salvatori P, Terova G, Moscone D, Lista F, Arduini F (2021) Magnetic beads combined with carbon black-based screen-printed electrodes for COVID-19: a reliable and miniaturized electrochemical immunosensor for SARS-CoV-2 detection in saliva. Biosens Bioelectron 171:112686

7. Fan Z, Yao B, Ding Y, Zhao J, Xie M, Zhang K (2021) Entropydriven amplified electrochemiluminescence biosensor for RdRp gene of SARS-CoV-2 detection with self-assembled DNA tetrahedron scaffolds. Biosens Bioelectron 178:113015

8. Bayin Q, Huang L, Ren C, Fu Y, Ma X, Guo J (2021) Anti-SARSCoV-2 IgG and IgM detection with a GMR based LFIA system. Talanta 227:122207

9. Karami A, Hasani M, Azizi Jalilian F, Ezati R (2021) Conventional PCR assisted single-component assembly of spherical nucleic acids for simple colorimetric detection of SARS-CoV-2. Sens Actuat BChem 328:128971

10. Moitra P, Alafeef M, Dighe K, Frieman MB, Pan D (2020) Selective naked-eye detection of SARS-CoV-2 mediated by N gene targeted antisense oligonucleotide capped plasmonic nanoparticles. ACS Nano 14:7617-7627

11. Funari R, Chu K, Shen AQ (2020) Detection of antibodies against SARS-CoV-2 spike protein by gold nanospikes in an optomicrofluidic chip. Biosens Bioelectron 169:112578

12. Bukkitgar SD, Shetti NP, Aminabhavi TM (2020) Electrochemical investigations for COVID-19 detection-a comparison with other viral detection methods. Chem Eng J 127575

13. Rashed MZ, Kopechek JA, Priddy MC, Hamorsky KT, Palmer KE, Mittal N, Valdez J, Flynn J, Williams SJ (2021) Rapid detection of SARS-CoV-2 antibodies using electrochemical impedance-based detector. Biosens Bioelectron 171:112709

14. Alafeef M, Dighe K, Moitra P, Pan D (2020) Rapid, ultrasensitive, and quantitative detection of SARS-CoV-2 using antisense oligonucleotides directed electrochemical biosensor chip. ACS Nano 14: 17028-17045

15. Eissa S, Alhadrami HA, Al-Mozaini M, Hassan AM, Zourob M (2021) Voltammetric-based immunosensor for the detection of SARS-CoV-2 nucleocapsid antigen. Microchim Acta 188:199

16. Das CM, Guo Y, Yang G, Kang L, Xu G, Ho H, Yong K (2020) Gold nanorod assisted enhanced plasmonic detection scheme of COVID-19 SARS-CoV-2 spike protein. AdvTheor Simul 3: 2000185

17. Soler M, Estevez MC, Cardenosa-Rubio M, Astua A, Lechuga LM (2020) How nanophotonic label-free biosensors can contribute to rapid and massive diagnostics of respiratory virus infections: COVID-19 case. ACS Sens 5:2663-2678

18. Roda A, Cavalera S, Di Nardo F, Calabria D, Rosati S, Simoni P, Colitti B, Baggiani C, Roda M, Anfossi L (2021) Dual lateral flow optical/chemiluminescence immunosensors for the rapid detection of salivary and serum IgA in patients with COVID-19 disease. Biosens Bioelectron 172:112765

19. Cady NC, Tokranova N, Minor A, Nikvand N, Strle K, Lee WT, Page W, Guignon E, Pilar A, Gibson GN (2021) Multiplexed detection and quantification of human antibody response to COVID19 infection using a plasmon enhanced biosensor platform. Biosens Bioelectron 171:112679

20. Quer G, Radin JM, Gadaleta M, Baca-Motes K, Ariniello L, Ramos E, Kheterpal V, Topol EJ, Steinhubl SR (2021) Wearable sensor data and self-reported symptoms for COVID-19 detection. Nat Med 27:73-77

21. Chaibun T, Puenpa J, Ngamdee T, Boonapatcharoen N, Athamanolap P, Mullane OAP, Vongpunsawad S, Poovorawan Y, Lee SY, Lertanantawong B (2021) Rapid electrochemical detection of coronavirus SARS-CoV-2. Nat Commun 12:802

22. Garg M, Sharma AL, Singh S (2021) Advancement in biosensors for inflammatory biomarkers of SARS-CoV-2 during 2019-2020. Biosens Bioelectron 171:112703

23. Chauhan DS, Prasad R, Srivastava R, Jaggi M, Chauhan SC, Yallapu MM (2020) Comprehensive review on current interventions, diagnostics, and nanotechnology perspectives against SARSCoV-2. Bioconjug Chem 31:2021-2045

24. Cui F, Zhou HS (2020) Diagnostic methods and potential portable biosensors for coronavirus disease 2019. Biosens Bioelectron 165: 112349

25. Xu L, Li D, Ramadan S, Li Y, Klein N (2020) Facile biosensors for rapid detection of COVID-19. Biosens Bioelectron 170:112673

26. Liu R, He L, Hu Y, Luo Z, Zhang J (2020) A serological aptamerassisted proximity ligation assay for COVID-19 diagnosis and seeking neutralizing aptamers. Chem Sci 11:12157-12164

27. Zakashansky JA, Imamura AH, Salgado DF, Romero Mercieca HC, Aguas RFL, Lao AM, Pariser J, Arroyo-Currás N, Khine M (2020) Detection of the SARS-CoV-2 spike protein in saliva with Shrinky-Dink@ electrodes. medRxiv2011-2020

28. Woo CH, Jang S, Shin G, Jung GY, Lee JW (2020) Sensitive fluorescence detection of SARS-CoV-2 RNA in clinical samples 
via one-pot isothermal ligation and transcription. Nat Biomed Eng 4:1168-1179

29. Cennamo N, Pasquardini L, Arcadio F, Lunelli L, Vanzetti L, Carafa V, Altucci L, Zeni L (2021) SARS-CoV-2 spike protein detection through a plasmonic D-shaped plastic optical fiber aptasensor. Talanta 233:122532

30. Akib TBA, Mou SF, Rahman MM, Rana MM, Islam MR, Mehedi IM, Mahmud MAP, Kouzani AZ (2021) Design and numerical analysis of a graphene-coated SPR biosensor for rapid detection of the novel coronavirus. Sensors 21:3491

31. Rezabakhsh A, Rahbarghazi R, Fathi F (2020) Surface plasmon resonance biosensors for detection of Alzheimer's biomarkers; an effective step in early and accurate diagnosis. Biosens Bioelectron 167:112511

32. Tripathi PK, Upadhyay S, Singh M, Raghavendhar S, Bhardwaj M, Sharma P, Patel AK (2020) Screening and evaluation of approved drugs as inhibitors of main protease of SARS-CoV-2. Int J Biol Macromol 164:2622-2631

33. Ye M, Luo G, Ye D, She M, Sun N, Lu Y, Zheng J (2020) Network pharmacology, molecular docking integrated surface plasmon resonance technology reveals the mechanism of Toujie Quwen Granules against coronavirus disease 2019 pneumonia. Phytomedicine 153401

34. Bong J, Kim T, Jung J, Lee SJ, Sung JS, Lee CK, Kang M, Kim HO, Pyun J (2020) Pig sera-derived anti-SARS-CoV-2 antibodies in surface plasmon resonance biosensors. Bio Chip J 14:358-368

35. Baldoneschi V, Palladino P, Banchini M, Minunni M, Scarano S (2020) Norepinephrine as new functional monomer for molecular imprinting: an applicative study for the optical sensing of cardiac biomarkers. Biosens Bioelectron 157:112161

36. Jain S, Paliwal A, Gupta V, Tomar M (2020) Refractive index tuning of $\mathrm{SiO}_{2}$ for long range surface plasmon resonance based biosensor. Biosens Bioelectron 168:112508

37. Chen S, Liu Y, Yu Q, Peng W (2021) Self-referencing SPR biosensing with an ultralow limit-of-detection using long-wavelength excitation. Sens Actuat B-Chem 327:128935

38. Qu L, Bai J, Peng Y, Han D, Ning B, Zhou H, Li S, Gao Z (2021) Detection of three different estrogens in milk employing SPR sensors based on double signal amplification using graphene. Food Anal Methods 14:54-65

39. Wu Q, Li N, Wang Y, Liu Y, Xu Y, Wei S, Wu J, Jia G, Fang X, Chen F, Cui X (2019) A 2D transition metal carbide MXene-based SPR biosensor for ultrasensitive carcinoembryonic antigen detection. Biosens Bioelectron 144:111697

40. Wu L, You Q, Shan Y, Gan S, Zhao Y, Dai X, Xiang Y (2018) Few-layer $\mathrm{Ti}_{3} \mathrm{C}_{2} \mathrm{~T}_{\mathrm{x}} \mathrm{MXene:} \mathrm{a} \mathrm{promising} \mathrm{surface} \mathrm{plasmon} \mathrm{resonance}$ biosensing material to enhance the sensitivity. Sens Actuat B-Chem 277:210-215

41. Md BH, Md AK, Md SH, Khondoker ZI, Md SH, M IP, Nibir M, Lway FA, Md AH, Md MR (2020) Numerical modeling of $\mathrm{MoS}_{2}-$ graphene bilayer-based high-performance surface plasmon resonance sensor: structure optimization for DNA hybridization. Opt Eng 59:1-21

42. Chen X, Xu W, Ding N, Ji Y, Pan G, Zhu J, Zhou D, Wu Y, Chen C, Song H (2020) Dual interfacial modification engineering with 2D MXene quantum dots and copper sulphide nanocrystals enabled high-performance perovskite solar cells. Adv Funct Mater 30: 2003295

43. Zhou B, Su M, Yang D, Han G, Feng Y, Wang B, Ma J, Ma J, Liu C, Shen C (2020) Flexible MXene/silver nanowire-based transparent conductive film with electromagnetic interference shielding and electro-photo-thermal performance. ACS Appl Mater Inter 12: 40859-40869

44. Yan L, Chen X, Liu X, Chen L, Zhang B (2020) In situ formed VOOH nanosheet arrays anchored on a $\mathrm{Ti}_{3} \mathrm{C}_{2} \mathrm{~T}_{\mathrm{x}}$ MXene as a highly efficient and robust synergistic electrocatalyst for boosting water oxidation and reduction. J Mater Chem A 8:23637-23644

45. Li G, Li N, Peng S, He B, Wang J, Du Y, Zhang W, Han K, Dang F (2021) Highly efficient $\mathrm{Nb}_{2} \mathrm{C}$ MXene cathode catalyst with uniform O-terminated surface for lithium-oxygen batteries. Adv Energy Mater 11:2002721

46. Deshmukh K, Kováŕík T, Khadheer Pasha SK (2020) State of the art recent progress in two dimensional MXenes based gas sensors and biosensors: a comprehensive review. Coordin Chem Rev 424: 213514

47. Song M, Pang S, Guo F, Wong M, Hao J (2020) Fluoride-free 2D niobium carbide MXenes as stable and biocompatible nanoplatforms for electrochemical biosensors with ultrahigh sensitivity. Adv Sci 7:2001546

48. Li X, Liu F, Huang D, Xue N, Dang Y, Zhang M, Zhang L, Li B, Liu D, Wang L, Liu H, Tao X (2020) Nonoxidized MXene quantum dots prepared by microexplosion method for cancer catalytic therapy. Adv Funct Mater 30:2000308

49. Mohammadniaei M, Koyappayil A, Sun Y, Min J, Lee M (2020) Gold nanoparticle/MXene for multiple and sensitive detection of oncomiRs based on synergetic signal amplification. Biosens Bioelectron 159:112208

50. Chia HL, Mayorga-Martinez CC, Antonatos N, Sofer Z, GonzalezJulian JJ, Webster RD, Pumera M (2020) MXene titanium carbidebased biosensor: strong dependence of exfoliation method on performance. Anal Chem 92:2452-2459

51. Wu Q, Li N, Wang Y, Xu Y, Wu J, Jia G, Ji F, Fang X, Chen F, Cui $X$ (2020) Ultrasensitive and selective determination of carcinoembryonic antigen using multifunctional ultrathin aminofunctionalized $\mathrm{Ti}_{3} \mathrm{C}_{2}$-MXene nanosheets. Anal Chem 92:33543360

52. He L, Duan F, Song Y, Guo C, Zhao H, Tian J, Zhang Z, Liu C, Zhang X, Wang P, Du M, Fang S (2017) 2D zirconium-based metal-organic framework nanosheets for highly sensitive detection of mucin 1: consistency between electrochemical and surface plasmon resonance methods. 2D Mater 4: 25098

53. Shao B, Liu Z, Zeng G, Wang H, Liang Q, He Q, Cheng M, Zhou C, Jiang L, Song B (2020) Two-dimensional transition metal carbide and nitride (MXene) derived quantum dots (QDs): synthesis, properties, applications and prospects. J Mater Chem A 8:75087535

54. Hughes ZE, Walsh TR (2017) Structural disruption of an adenosine-binding DNA aptamer on graphene: implications for aptasensor design. ACS Sensors 2:1602-1611

55. Xi H, Juhas M, Zhang Y (2020) G-quadruplex based biosensor: a potential tool for SARS-CoV-2 detection. Biosens Bioelectron 167: 112494

56. Wu X, Chen J, Wu M, Zhao JX (2015) Aptamers: active targeting ligands for cancer diagnosis and therapy. Theranostics 5:322-344

57. Xue Q, Zhang H, Zhu M, Pei Z, Li H, Wang Z, Huang Y, Huang Y, Deng Q, Zhou J, Du S, Huang Q, Zhi C (2017) Photoluminescent $\mathrm{Ti}_{3} \mathrm{C}_{2}$ MXene quantum dots for multicolor cellular imaging. Adv Mater 29:1604847

58. Li S, Qiu W, Zhang X, Ni J, Gao F, Wang Q (2016) A highperformance DNA biosensor based on the assembly of gold nanoparticles on the terminal of hairpin-structured probe DNA. Sensor Actuat B-Chem 223:861-867

59. Tian Y, Bu T, Zhang M, Sun X, Jia P, Wang Q, Liu Y, Bai F, Zhao S, Wang L (2021) Metal-polydopamine framework based lateral flow assay for high sensitive detection of tetracycline in food samples. Food Chem 339:127854

60. Hu Y, Xie X, Wang X, Wang Y, Zeng Y, Pui DYH, Sun J (2018) Visible-light upconversion carbon quantum dots decorated $\mathrm{TiO}_{2}$ for the photodegradation of flowing gaseous acetaldehyde. Appl Surf Sci 440:266-274 
61. Hu W, Liu Y, Withers RL, Frankcombe TJ, Norén L, Snashall A, Kitchin M, Smith P, Gong B, Chen H, Schiemer J, Brink F, WongLeung J (2013) Electron-pinned defect-dipoles for highperformance colossal permittivity materials. Nat Mater 12:821-826

62. Han J, Liu Z, Ma Y, Cui G, Xie F, Wang F, Wu Y, Gao S, Xu Y, Sun $\mathrm{X}$ (2018) Ambient $\mathrm{N}_{2}$ fixation to $\mathrm{NH}_{3}$ at ambient conditions: using $\mathrm{Nb}_{2} \mathrm{O}_{5}$ nanofiber as a high-performance electrocatalyst. Nano Energy 52:264-270

63. Wu F, Yue L, Su H, Wang K, Yang L, Zhu X (2018) Carbon dots@platinum porphyrin composite as theranostic nanoagent for efficient photodynamic cancer therapy. Nanoscale Res Lett 13:357

64. Zheng X, Wu J, Cao X, Abbott J, Jin C, Wang H, Strasser P, Yang R, Chen X, Wu G (2019) N-, P-, and S-doped graphene-like carbon catalysts derived from onium salts with enhanced oxygen chemisorption for Zn-air battery cathodes. Appl Catal B-Environ 241: $442-451$

65. Luo X, Ren H, Ma H, Yin C, Wang Y, Li X, Shen Z, Wang Y, Cui $\mathrm{L}$ (2020) In situ integration of $\mathrm{Co}_{5.47} \mathrm{~N}$ and $\mathrm{Co}_{0.72} \mathrm{Fe}_{0.28}$ alloy nanoparticles into intertwined carbon network for efficient oxygen reduction. J Colloid Interf Sci 569:267-276

66. Yu Z, Luan Y, Li H, Wang W, Wang X, Zhang Q (2019) A disposable electrochemical aptasensor using single-stranded DNAmethylene blue complex as signal-amplification platform for sensitive sensing of bisphenol A. Sensor Actuat B-Chem 284:73-80

67. Wijaya E, Lenaerts C, Maricot S, Hastanin J, Habraken S, Vilcot J, Boukherroub R, Szunerits S (2011) Surface plasmon resonance- based biosensors: from the development of different SPR structures to novel surface functionalization strategies. Curr Opin Solid St M $15: 208-224$

68. Li C, Li J, Yang X, Gao L, Jing L, Ma X (2017) A label-free electrochemical aptasensor for sensitive myoglobin detection in meat. Sensor Actuat B-Chem 242:1239-1245

69. Chen X, Yamaguchi A, Namekawa M, Kamijo T, Teramae N, Tong A (2011) Functionalization of mesoporous silica membrane with a Schiff base fluorophore for $\mathrm{Cu}(\mathrm{II})$ ion sensing. Anal Chim Acta 696:94-100

70. Huang C, Yao Y, Montes García V, Stoeckel M, von Holst M, Ciesielski A, Samorì P (2021) Highly sensitive strain sensors based on molecules-gold nanoparticles networks for high-resolution human pulse analysis Small 2007593

71. Jing M, Bowser M (2011) Methods for measuring aptamer-protein equilibria: a review. Anal Chim Acta 686:9-18

72. Duan F, Zhang S, Yang L, Zhang Z, He L, Wang M (2018) Bifunctional aptasensor based on novel two-dimensional nanocomposite of $\mathrm{MoS}_{2}$ quantum dots and $\mathrm{g}-\mathrm{C}_{3} \mathrm{~N}_{4}$ nanosheets decorated with chitosan-stabilized $\mathrm{Au}$ nanoparticles for selectively detecting prostate specific antigen. Anal Chim Acta 1036:121-132

Publisher's note Springer Nature remains neutral with regard to jurisdictional claims in published maps and institutional affiliations. 